\title{
PRAWO MIĘDZYNARODOWE WOBEC MOŻLIWOŚCI POZBAWIENIA OBYWATELSTWA ZA DZIAŁALNOŚĆ TERRORYSTYCZNĄ
}

Do niedawna zagadnienia związane z możliwością pozbawienia jednostki obywatelstwa ze względu na zagrożenie dla bezpieczeństwa państwa nie przyciągały większej uwagi ani decydentów politycznych, ani przedstawicieli doktryny prawa międzynarodowego. Sytuacja uległa zmianie, gdy część państw postanowiła uchwalić nowe lub zmodyfikować istniejące przepisy w taki sposób, aby umożliwić pozbawienie obywatelstwa osób, które uczestniczą w aktach terrorystycznych w kraju lub — coraz częściej — poza jego granicami. W większości przypadków zmianę dotychczasowego podejścia spowodował problem tzw. zagranicznych bojowników terrorystycznych, czyli osób, które najpierw opuszczają macierzyste państwa w celu dołączenia do różnych ugrupowań terrorystycznych, a następnie powracają do swoich krajów. Autor podjął próbę ustalenia, czy normy współczesnego prawa międzynarodowego dają podstawy do pozbawienia obywatelstwa z uwagi na zaangażowanie jednostki w działalność terrorystyczną. Udzielając pozytywnej odpowiedzi na tak postawione pytanie, zarazem zastanawia się, jak daleko państwa mogą się posunąć w zakresie realizowania posiadanego uprawnienia oraz na ile odpowiednie normy i zasady prawa międzynarodowego ograniczają swobodę państw w tym zakresie.

Słowa kluczowe: pozbawienie obywatelstwa, zagraniczni bojownicy terrorystyczni, prawo międzynarodowe, arbitralność, bezpaństwowość

\section{INTERNATIONAL LAW AGAINST THE POSSIBILITY OF CITIZENSHIP DEPRIVATION FOR TERRORIST ACTIVITY}

Until recently, the question of citizenship deprivation for national security reasons had not attracted much attention among policymakers and international scholars. Things changed after some states had enacted or amended their laws so as to permit denationalization of their citizens engaged in terrorist activities at home or — which is more often the case — abroad. In most countries this shift was a response to the problem of "foreign terrorist fighters", namely terrorist fighters who first leave their home country to join terrorist organizations abroad and then return. This article examines in detail the question of whether or not it is possible under international law to deprive a person of his/her citizenship because of involvement in terrorist activities. While answering this question affirmatively, the author wonders how far states can go in the exercise of citizenship deprivation powers and to what extent relevant norms and principles of international law limit state powers in this regard.

Key words: deprivation of citizenship, foreign terrorist fighters, international law, arbitrariness, statelessness

* Dr Marcin Pączek, Uniwersytet Rzeszowski, Wydział Prawa i Administracji, Zakład Prawa Międzynarodowego i Prawa Europejskiego, paczek_marcin@tlen.pl, https://orcid.org/0000-0003-1887-4630 


\section{UWAGI WPROWADZAJĄCE}

W spółczesny terroryzm stawia coraz większe wyzwania i stwarza coraz to nowe zagrożenia dla społeczności międzynarodowej. W ostatnich latach do rangi jednego z głównych zagrożeń tego rodzaju urósł problem tzw. zagranicznych bojowników terrorystycznych (foreign terrorist fighters) ${ }^{1}$. Chodzi o osoby, które — zgodnie z rezolucją Rady Bezpieczeństwa ONZ nr 2178 (2014) — podróżują do państwa niebędącego państwem ich obywatelstwa lub stałego zamieszkania, w celu ,popełnienia, planowania, przygotowania lub uczestniczenia $\mathrm{w}$ aktach terrorystycznych albo w celu przeprowadzenia szkolenia terrorystycznego lub otrzymania takiego szkolenia"'2. Dokładna liczba takich osób jest stosunkowo trudna do oszacowania, niemniej zauważa się, że z upływem lat wykazuje tendencję wzrostową. Według niektórych danych w samych tylko strukturach tzw. państwa islamskiego mogło dotąd walczyć od 15 do nawet 28 tys. cudzoziemców z ponad 100 państw na całym świecie³. Szacuje się jednocześnie, że ok. 5 tys. takich osób pochodziło z Europy, w zdecydowanej większości z Wielkiej Brytanii, Belgii, Francji oraz Niemiec ${ }^{4}$.

Intensyfikacja działań na arenie międzynarodowej, prowadzących do pozbawienia ugrupowań terrorystycznych schronienia oraz możliwości swobodnego operowania na terytoriach państwowych (głównie na Środkowym Wschodzie), zmusiła wielu zagranicznych bojowników do powrotu do krajów pochodzenia ${ }^{5}$. Zwróciło to uwagę na potrzebę zapewnienia pozostałym obywatelom odpowiedniego stopnia ochrony przed zagrożeniami, jakie może nieść ze sobą powrót wspomnianych osób do swoich państw macierzystych. Przewodniczący Komitetu Antyterrorystycznego ONZ zaapelował w tym kontekście do państw członkowskich m.in. o: skuteczniejsze egzekwowanie odpowiedzialności karnej od powracających bojowników terrorystycznych, lepsze wykorzystywanie instrumentów międzynarodowej pomocy prawnej przy ściganiu takich osób, usprawnienie kontroli granicznych, zapobieganie rekrutowaniu wśród własnych obywateli osób potencjalnie zainteresowanych działalnością terrorystyczną czy wreszcie o wdrożenie odpowiednich programów rehabilitacji i reintegracji społecznej, których celem będzie zwalczanie radykalnych postaw i nastrojów u osób

1 Vide OSCE Office for Democratic Institutions and Human Rights, Guidelines for addressing the threats and challenges of "foreign terrorist fighters" within a human rights framework (2018), <www.osce. org>, dostęp 15 IV 2019; United Nations Office on Drugs and Crime, Foreign terrorist fighters. Manual for judicial training institutes South-Eastern Europe, Vienna 2017.

${ }^{2}$ UN Doc. S/RES/2178 (2014), 24 September 2014, preambuła $§ 9$.

${ }^{3}$ O. Wasiuta, S. Wasiuta, Rekrutacja bojowników-cudzoziemców do ISIS, „Annales Universitatis Paedagogicae Cracoviensis - Studia de Securitate et Educatione Civili” 2017, nr 7, s. 5.

${ }^{4}$ E.U. Ochab, Attempts to address the issue of foreign terrorist fighters continue, „Forbes”, 22 II 2019, $<$ www.forbes.com>, dostęp 15 IV 2019.

${ }^{5}$ Do tego momentu mogło to uczynić nawet $30 \%$ cudzoziemców zaangażowanych w działalność terrorystyczną na terytoriach położonych w Iraku oraz Syrii; vide S. See, Returning foreign terrorist fighters: A catalyst for recidivism among disengaged terrorists, „Counter Terrorist Trends and Analyses” 2018, t. 10 , nr 6, s. 7. 
zaangażowanych dotychczas $\mathrm{w}$ działalność terrorystyczną ${ }^{6}$. Tymczasem - jak pokazuje praktyka - wiele państw zdecydowało się zastosować odmienne rozwiązanie i dopuściło możliwość pozbawienia obywatelstwa osób, które zostały skazane lub są podejrzane o prowadzenie działalności terrorystycznej w państwie swojego pochodzenia lub poza jego granicami. Formalna utrata obywatelstwa przez takie osoby ma im uniemożliwiać docelowy powrót do państwa pochodzenia lub, jeżeli już się w nim znajdują, pozwalać na ich ewentualne wydalenie.

Zasygnalizowana praktyka wymaga bliższego przyjrzenia się ewentualnym podstawom i warunkom pozbawienia obywatelstwa $z$ uwagi na prowadzenie przez obywatela działalności terrorystycznej w państwie pobytu lub w państwie pochodzenia. W tym celu przedstawiono istotę obywatelstwa oraz rolę norm prawa międzynarodowego $\mathrm{w}$ tym zakresie. Następnie poddano analizie samą możliwość pozbawienia obywatelstwa z uwagi na dopuszczanie się przestępstw o charakterze terrorystycznym. W dalszej kolejności scharakteryzowano najważniejsze ograniczenia, jakie prawo międzynarodowe nakłada na państwa, tj. zakaz arbitralnego pozbawiania obywatelstwa oraz konieczność unikania statusu bezpaństwowości.

\section{KOMPETENCJA WLASNA PAŃSTWA I JEJ OGRANICZENIA W SPRAWACH DOTYCZĄCYCH OBYWATELSTWA}

Obywatelstwo jest zwykle definiowane jako rodzaj więzi prawnej łączącej jednostkę z państwem. Instytucja ta określa formalne członkostwo jednostki w zorganizowanej wspólnocie politycznej opartej na istnieniu wzajemnych praw i obowiązków ${ }^{7}$. Takie postrzeganie obywatelstwa w pełni odpowiada definicji sformułowanej przez Międzynarodowy Trybunał Sprawiedliwości w sprawie Nottebohma. Trybunał podkreślił bowiem, że: „obywatelstwo jest węzłem prawnym, u podstaw którego leży fakt przywiązania, efektywności bytu i uczuć, połączona z wzajemnością praw i obowiązków. Jest ono prawnym wyrazem faktu wskazującego na to, że jednostka, której je nadano bądź skutkiem ustawy, bądź aktem władzy, jest faktycznie ściśle związana z ludnością państwa, które jej obywatelstwo nadaje, niż z ludnością innego państwa"8. Z wytworzonych w ten sposób związków między państwem a obywatelem wynika szereg konsekwencji zarówno w prawie krajowym, jak i międzynarodowym. Jedną z nich jest obowiązek przyjmowania przez państwo własnych obywateli oraz zakaz ich wydalania ze swojego terytorium. W doktrynie wyrażono nawet pogląd, że odnośne obowiązki państw uzyskały

${ }^{6}$ Vide Letter dated 28 December 2018 from the Chair of the Security Council Committee established pursuant to resolution 1373 (2001) concerning counter-terrorism addressed to the President of the Security Council, Annex: Addendum to the guiding principles on foreign terrorist fighters (2018), UN Doc. $\mathrm{S} / 2018 / 1177, \S 6$.

7 D.E. Harasimiuk, Obywatelstwo UE - element tożsamości narodowej, europejskiej, czy jedynie dodatkowy status obywateli państw członkowskich?, „Ius Novum” 2017, nr 3, s. 123.

${ }^{8}$ Nottebohm case (Liechtenstein v. Guatemala), International Court of Justice, Judgment of 6 April 1955, ICJ Reports 1955, s. 23. Polskie tłumaczenie wyroku vide Prawo międzynarodowe publiczne. Wybór orzecznictwa, red. P. Daranowski, J. Połatyńska, Warszawa 2011, s. 95.

${ }^{9}$ Confer art. 3 Protokołu nr 4 do Konwencji o ochronie praw człowieka i podstawowych wolności, gwarantującego niektóre prawa i wolności, inne niż zawarte w Konwencji i w pierwszym Protokole 
z czasem status norm międzynarodowego prawa zwyczajowego ${ }^{10}$. W związku z tym niezwykle trudna - by nie powiedzieć, że wręcz niemożliwa - jest odmowa przyjęcia obywatela przez państwo pochodzenia albo wydalenie z tego państwa, bez uprzedniego pozbawienia go obywatelstwa.

W prawie międzynarodowym sprawy obywatelstwa należą zasadniczo do kompetencji własnej państwa, które w swoim ustawodawstwie określa, jakim osobom obywatelstwo przysługuje oraz w jaki sposób można je nabyć lub utracić ${ }^{11}$. W praktyce oznacza to, że każde państwo samodzielnie decyduje, czy doszło do wytworzenia rzeczywistej więzi, która uzasadniałaby przyznanie jednostce obywatelstwa. Oznacza to również, że do kompetencji wewnętrznej państwa i jego organów należy ocena, czy wskutek pewnych działań lub zaniechań jednostki nie doszło do zaniku powstałej wcześniej więzi albo nie okazało się, że więź ta faktycznie nigdy nie została wytworzona, co w konsekwencji mogłoby skutkować pozbawieniem danej osoby posiadanego obywatelstwa. W tym kontekście warto zaznaczyć, że decydując się na pozbawienie jednostki obywatelstwa, państwa uzasadniają to najczęściej m.in.: dobrowolnym przyjęciem obywatelstwa innego państwa, nabyciem obywatelstwa za pomocą oszustwa lub zatajenia istotnych informacji, dobrowolną służbą wojskową w siłach zbrojnych innego państwa, zachowaniem szkodzącym żywotnym interesom państwa czy niekiedy nawet stałym zamieszkiwaniem na terytorium innego państwa ${ }^{12}$.

Kompetencja własna państwa do regulowania spraw związanych z obywatelstwem podlega jednak pewnym ograniczeniom wynikającym z prawa międzynarodowego. Współczesne ograniczenia możliwości swobodnego kształtowania instytucji obywatelstwa w prawodawstwie wewnętrznym mogą wynikać chociażby z umów międzynarodowych, które zobowiązują państwa do wprowadzenia do swojego systemu prawa krajowego zasad i norm przewidzianych w tych umowach ${ }^{13}$. Znajduje

dodatkowym do Konwencji, Strasburg, 16 września 1963 r., „European Treaty Series” [dalej: ETS] nr 046; art. 22 ust. 5 Amerykańskiej konwencji praw człowieka, San Jose, 22 listopada 1969 r., <www.refworld. org>, dostęp 15 IV 2019; art. 22 Arabskiej Karty Praw Człowieka, Kair, 15 września 1994 r., <www. refworld.org >, dostęp 15 IV 2019.

${ }_{10}$ Tak np. vide Y. Ronen, Transition from illegal regimes under international law, Cambridge 2011, s. 187. Zbliżone stanowisko zaprezentował specjalny sprawozdawca Komisji Prawa Międzynarodowego, M. Kamto, przedstawiając Komisji swój trzeci raport z prac nad zagadnieniem wydalania cudzoziemców. Zauważył on rzecz następującą: ,Given the abundant national and international practice [...] and doctrinal opinions on the subject, which is long-standing and nearly unanimous, there is cause to be - at the very least — cautious about the statement that «a general rule of customary international law forbidding the expulsion of nationals does not exist». In fact, the principle of the prohibition of expulsion by a State of its own nationals is indisputable in international law [...] Whether it takes the form of a customary rule or a general tenet of law, the principle exist in international law", vide International Law Commission, Third Report on the expulsion of aliens (By Mr. Maurice Kamto, Special Rapporteur), 19 April 2007, UN Doc. A/CN.4/581, §39.

11 R. Bierzanek, J. Symonides, Prawo międzynarodowe publiczne, Warszawa 2005, s. 257.

12 Confer np. art. 7 ust. 1 Europejskiej konwencji o obywatelstwie, Strasburg, 6 listopada 1997 r., ETS nr 166.

13 E. Dynia, Obywatelstwo w świetle prawa międzynarodowego, „Annales Universitatis Mariae Curie-Skłodowska. Sectio G” 2000, t. XLVII, s. 25. Podobnie vide W. Czapliński, Międzynarodowe aspekty obywatelstwa, „Ruch Prawniczy, Ekonomiczny i Socjologiczny” 1984, z. 3, s. 96-98. 
to potwierdzenie w utrwalonym orzecznictwie międzynarodowym oraz w treści odpowiednich aktów prawa międzynarodowego. Stały Trybunał Sprawiedliwości Międzynarodowej, rozpoznając kwestię legalności regulowania przez rząd francuski spraw związanych z obywatelstwem w swoich protektoratach w Tunezji i Maroku, stwierdził, że „W sprawach dotyczących obywatelstwa, które, co do zasady, nie są normowane przez prawo międzynarodowe, prawo państw do korzystania z posiadanych uprawnień, może być ograniczone zobowiązaniami, które państwa zaciągnęły względem innych państw"14. Do źródeł takich zobowiązań zgodnie z konwencją haską z 1930 r. zalicza się umowy międzynarodowe, zwyczaj międzynarodowy oraz powszechnie uznane zasady odnoszące się do obywatelstwa ${ }^{15}$.

Rozwój prawa międzynarodowego, w szczególności praw człowieka, doprowadził w konsekwencji do ukształtowania szeregu zasad, które w różnym stopniu ograniczają uznaniowość państw przy podejmowaniu decyzji o pozbawieniu jednostki obywatelstwa. Dla przykładu Europejska konwencja o obywatelstwie z 1997 r. zobowiązuje strony do oparcia swojego ustawodawstwa na następujących zasadach: każdy człowiek ma prawo do posiadania obywatelstwa, należy unikać statusu bezpaństwowości, zakazane jest arbitralne pozbawianie obywatelstwa, zawarcie lub rozwiązanie związku małżeńskiego z cudzoziemcem nie skutkuje automatyczną utratą obywatelstwa, należy kierować się obowiązkiem jednakowego traktowania obywateli bez względu na sposób nabycia obywatelstwa ${ }^{16}$. Wiele $\mathrm{z}$ wymienionych zasad uzyskało charakter prawa zwyczajowego i - co za tym idzie - wiążą one państwa niezależnie od innych podstaw ich obowiązywania. Rozważając zatem dopuszczalność pozbawienia obywatelstwa z uwagi na działalność terrorystyczną, należy w pierwszej kolejności ustalić, czy wykorzystanie takiej przesłanki w ustawodawstwie wewnętrznym nie jest ab initio sprzeczne z treścią międzynarodowych zobowiązań państw w tym zakresie.

\section{DZIALALNOŚĆ TERRORYSTYCZNA JAKO MOŻLIWA PODSTAWA POZBAWIENIA OBYWATELSTWA}

Zagrożenie stwarzane przez obywateli w zakresie ładu społecznego państwa tradycyjnie było uznawane za najważniejszą, jeżeli nie jedyną, podstawę pozbawienia obywatelstwa. $\mathrm{Z}$ jednej strony pozwalało to na legalną ekspulsję obywateli z państwa pochodzenia, z drugiej natomiast służyło symbolicznemu podkreśleniu zaniku istniejących dotąd więzi między jednostką winną określonych czynów a resztą społeczeństwa. Wprawdzie katalog zachowań dających postawy do odebrania obywatelstwa z biegiem czasu uległ istotnemu zawężeniu oraz pewnej redefinicji, niemniej działania traktowane jako poważne zagrożenie dla porządku publicznego państwa stale były w tym katalogu

${ }^{14}$ National decrees issued in Tunis and Morocco, Permanent Court of International Justice [dalej: PCIJ], Advisory Opinion No. 4 of 7 February 1923, PCIJ Publ. seria B, 1923, nr 4, s. 24.

15 Confer art.1 Konwencji w sprawie niektórych zagadnień dotyczących konfliktu ustaw o obywatelstwie, Haga, 12 kwietnia 1930 r., ,League of Nations Treaty Series”, t. 179, nr 4137, s. 89.

${ }^{16}$ Confer art. 4 oraz art. 5 Europejskiej konwencji o obywatelstwie. 
obecne $^{17}$. Sytuacji tej zasadniczo nie zmieniły — częste w okresie międzywojennym przypadki nadużywania posiadanych uprawnień przez różne autorytarne reżimy, które dopuszczały się masowego pozbawiania obywatelstwa swoich przeciwników, traktując to jako instrument terroru i represji politycznej.

Współcześnie reminiscencje takiego podejścia można znaleźć w ustawodawstwie krajowym państw, w których pozwala się na pozbawienie jednostki obywatelstwa z uwagi na zachowania postrzegane jako zagrożenie dla szeroko pojętego porządku publicznego. Niewątpliwie niektóre $\mathrm{z}$ tych zachowań pośrednio można uznać za prowadzenie działalności o charakterze terrorystycznym. W ustawodawstwie wewnętrznym znane są bowiem takie przesłanki utraty obywatelstwa, jak m.in. skazanie za ciężkie przestępstwa popełnione na szkodę państwa, stwarzanie poważnego i systematycznego zagrożenie dla współobywateli, zamach na porządek konstytucyjny państwa, członkostwo w ugrupowaniach i stowarzyszeniach prowadzących działalność mającą na celu podważenie podstaw ustroju społecznego, gospodarczego i politycznego państwa czy wreszcie demonstrowanie, za pomocą czynów lub mowy, braku przywiązania i lojalności względem państwa obywatelstwa ${ }^{18}$. Warto dodać, że w ponad połowie państw członkowskich Unii Europejskiej dopuszczono możliwość pozbawienia obywatelstwa z uwagi na wystąpienie przynajmniej jednej ze wskazanych przesłanek ${ }^{19}$. Działalność terrorystyczna została wymieniona wprost $\mathrm{w}$ ustawodawstwie wewnętrznym Francji ${ }^{20}$, Włoszech ${ }^{21}$, Rumunii ${ }^{22}$ oraz Czarnogóry ${ }^{23}$, a spośród państw pozaeuropejskich chociażby w prawodawstwie Mongolii24.

17 S. Mantu, Contingent citizenship. The law and practice of citizenship deprivation in international, european and national perspectives, Leiden-Boston 2015, s. 16-17; W. Walters, Deportation, expulsion, and the international police of aliens, „Citizenship Studies” 2002, t. 6, nr 3, s. 265-292.

${ }_{18}$ Council of Europe, Nationality issues and the denial of residence in the context of the fight against terrorism - feasibility study (prepared by Mr. Andrew Walmsley), Strasbourg, 5 December 2006, Doc. CDCJ-BU (2006) 22, s. 10-11.

${ }^{19} \mathrm{~W}$ ustawodawstwie Belgii, Bułgarii, Danii oraz Holandii przewidziano możliwość odebrania obywatelstwa z powodu popełnienia poważnego przestępstwa przeciwko państwu; działalności godzącej w podstawy porządku konstytucyjnego oraz systemu instytucjonalnego państwa co stanowi z kolei podstawę do odebrania obywatelstwa w Danii, Estonii, Francji, na Litwie oraz Łotwie; okazywanie braku lojalności względem państwa - na Cyprze, Malcie oraz w Irlandii; natomiast prowadzenie działalności sprzecznej z ,interesem narodowym”, może być podstawą odebrania obywatelstwa w Grecji, Francji, Rumunii, Słowenii oraz w Zjednoczonym Królestwie, vide European Parliament, Acquisition and loss of citizenship in EU Member States: Key trends and issues, <www.europarl.europa.eu>, dostęp 15 IV 2019.

${ }^{20}$ French Civil Code, art. 25, <www.legifrance.gouv.fr>, dostęp 15 IV 2019.

${ }^{21}$ Decree Law on Citizenship of Italy, art. 14, vide A. Vedaschi, Ch. Graziani, Citizenship revocation in Italy as a counter terrorism measure, < verfassungsblog.de>, dostęp 15 IV 2019.

${ }^{22}$ Law No. 21/1991 on Romanian Citizenship [Romania], 5 April 1991, art. 25 ust. 1 lit. d, <www. refworld.org>, dostęp 15 IV 2019.

${ }^{23}$ Law No. 01-288/2 of 2008 on Montenegrin Citizenship (2014) [Montenegro], 21 February 2008, art. 24(5), https://www.refworld.org, dostęp 15 IV 2019.

${ }^{24}$ Law of Mongolia on Citizenship (as amended on 7 December 2000) [Mongolia], 5 June 1995, https://www.refworld.org, dostęp 15 IV 2019. 
Przegląd aktualnej praktyki państw pozwala stwierdzić, że dopuszczenie możliwości pozbawienia obywatelstwa z uwagi na działalność terrorystyczną jest nie tylko uregulowane w prawie, ale nierzadko bywa również wykorzystywane jako realny instrument przeciwdziałania zagrożeniom, którym w inny sposób państwo nie jest w stanie zapobiec. Wystarczy nadmienić, że w latach 2003-2012 brytyjskie władze pozbawiły obywatelstwa 27 osób, uzasadniając to względami bezpieczeństwa narodowego. W sierpniu 2014 r. Kuwejt pozbawił swojego obywatelstwa 15 osób, w tym część z powodu udzielania finansowego wsparcia organizacjom terrorystycznym ${ }^{25}$. Podobnie zachował się minister spraw wewnętrznych Australii, który w 2018 r. wydał decyzję o utracie obywatelstwa przez osobę skazaną w Turcji na karę pozbawienia wolności za działalność na rzecz państwa islamskiego ${ }^{26}$.

Mając na uwadze wymienione okoliczności, trudno zgodzić się z tezą, że zakaz pozbawiania jednostki obywatelstwa ze względu na działalność terrorystyczną znajduje podstawę $\mathrm{w}$ powszechnym prawie międzynarodowym. $\mathrm{Z}$ całą pewnością nie wynika on z międzynarodowego prawa zwyczajowego, co potwierdzają choćby przepisy krajowe oraz praktyka ich stosowania. Z kolei w prawie traktatowym, którego zakres oddziaływania na praktykę państw w omawianym zakresie jest zdecydowanie węższy, także nie sformułowano takiego kategorycznego zakazu. Zgodnie z Konwencją o ograniczeniu bezpaństwowości z 1961 r., będącą w zasadzie jedynym relewantnym w tym zakresie instrumentem prawnym o uniwersalnym charakterze, wymaga się jedynie, aby pozbawienie obywatelstwa nie wiązało się z uzyskaniem przez jednostkę statusu bezpaństwowca ${ }^{27}$. Od tej zasady przewidziano jednak pewien wyjątek, o czym będzie jeszcze mowa w dalszej części opracowania. Natomiast jeżeli chodzi o instrumenty regionalne, to w Konwencji Rady Europy o obywatelstwie z 1997 r. dopuszczono pozbawienie jednostki obywatelstwa w przypadku postępowania poważnie szkodzącego ,żywotnym interesom strony"28, przy jednoczesnym zastrzeżeniu, że takie działania również nie mogą prowadzić do bezpaństwowości. Zwrot „postępowanie poważnie szkodzące żywotnym interesom" nie został wprawdzie doprecyzowany w treści konwencji, niemniej w załączonym raporcie wyjaśniającym znalazł się zapis, że „formuła «postępowanie poważnie szkodzące żywotnym interesom strony» została zaczerpnięta z art. 8 par. 3(a) ii Konwencji z 1961 r. o ograniczaniu bezpaństwowości. Zachowanie, o którym mowa, obejmuje w szczególności zdradę oraz inną aktywność wymierzoną przeciwko żywotnym interesom danego państwa (np. służbę na rzecz obcego wywiadu), nie obejmuje natomiast

${ }^{25}$ L. Esbrook, Citizenship unmoored: Expatriation as a counter-terrorism tool, „University of Pennsylvania Journal of International Law” 2016, t. 37, nr 4, s. 1286,1290.

${ }^{26}$ Department of Home Affairs of Australia, Neil Prakash stripped of Australian citizenship, <minister. homeaffairs.gov.au>, dostęp 16 IV 2019.

${ }^{27}$ Convention on the reduction of statelessness, New York, 30 August 1961, art. 8; United Nations Treaty Series [dalej: UNTS], t. 989, s. 175 i n.

${ }^{28}$ Confer art. 7 ust. 1 lit. d. Europejskiej konwencji o obywatelstwie. Na zagrożenia związane z możliwością nadużywania tej formuły zwraca uwagę m.in. W. Czapliński, Problematyka obywatelstwa w aktualnych pracach Rady Europy, „Studia Europejskie” 1998, nr 2, s. 54-55. 
przestępstw ogólniejszej natury, niezależnie od ich ciężaru gatunkowego"229. Zbyt dużym uproszczeniem byłoby jednak twierdzenie, że zgodnie ze stanowiskiem zaprezentowanym w raporcie wyjaśniającym wyklucza się możliwość uznania przestępstw terrorystycznych za zachowania przynoszące poważną szkodę ,ż̇ywotnym interesom” państw. Świadczy o tym kilka ważnych czynników. Po pierwsze, powołany raport wyjaśniający, podobnie zresztą jak inne dokumenty tego rodzaju, nie ma mocy wiążącej, a służy jedynie jako pomocniczy środek interpretacji przepisów traktatowych. Po drugie, praktyka stron konwencji z 1997 r. przeczy poglądowi wyrażonemu w raporcie. Poza wspomnianą wcześniej Rumunią oraz Czarnogórą, które w swoim prawodawstwie działalność terrorystyczną uznały wprost za uzasadnioną przesłankę utraty obywatelstwa, wiele pozostałych stron konwencji zawarło w swoim prawie krajowym odesłanie do przestępstw, które pośrednio obejmują również działalność terrorystyczną ${ }^{30}$. Holandia poszła nawet o krok dalej i dopuściła możliwość utraty obywatelstwa w przypadku popełnienia jakiegokolwiek przestępstwa zagrożonego sankcją karną w pewnej minimalnej wysokości ${ }^{31}$. W wymienionych przypadkach strony konwencji z 1997 r. najprawdopodobniej kierowały się przekonaniem, że klauzula dotycząca zagrożenia ,żywotnych interesów” nie ogranicza obejmowanych nią czynów jedynie do zachowań, które zostały wymienione w raporcie, ale obejmuje również inne poważne przestępstwa. Po trzecie wreszcie, przedstawiając w 2013 r. Radzie Praw Człowieka jeden z raportów na temat obywatelstwa, sekretarz generalny ONZ odnotował, że zarówno w konwencji z 1997 r., jak i w tej z 1961 r., wprowadzono zakaz pozbawiania obywatelstwa jedynie za dopuszczenie się zwyczajnych (ordinary) przestępstw. Nie znalazł natomiast podstaw, aby ten sam zakaz stosować do poważnej (serious) przestępczości. Zauważył przy tym, że w zależności od rozwiązań obowiązujących w poszczególnych państwach, o powadze czynu decyduje najczęściej albo wysokość ustawowego zagrożenia karą, albo rodzaj popełnionego przestępstwa ${ }^{32}$. W tej sytuacji nie powinno raczej budzić większych wątpliwości, że przestępczość terrorystyczna zasadniczo będzie wchodzić w zakres każdej ze wskazanych przesłanek.

\section{DZIALALNOŚĆ TERRORYSTYCZNA}

\section{A ZAKAZ ARBITRALNEGO POZBAWIANIA OBYWATELSTWA}

Dotychczasowa analiza pozwala zaobserwować, że prowadzenie działalności terrorystycznej może stanowić jedną z dopuszczalnych podstaw do pozbawienia jednostki

${ }^{29}$ Vide Explanatory Report to the European Convention on Nationality, Strasbourg, 6.11.1997; ETS nr 166, § 67.

${ }^{30}$ Przykładowo vide Federal Law Concerning the Austrian Nationality (Nationality Act 1985) (last amended 2006) [Austria], 30 July 1985, art. 33 (2), <www.refworld.org>, dostęp 16 IV 2019; Law on Citizenship of Bosnia and Herzegovina [Bosnia and Herzegovina], 27 July 1999, art. 23(2), <www.refworld. org>, dostęp 16 IV 2019; Law for the Bulgarian Citizenship (last amended February 2013) [Bulgaria], 5 November 1998, art. 24, <www.refworld.org>, dostęp 16 IV 2019; Act on the Acquisition of Danish Nationality (amended to 2004) [Denmark], 7 June 2004, art. 8B(1), <www.refworld.org>, dostęp 16 IV 2019.

${ }^{31}$ Netherlands Nationality Act, 2010 (as amended in 2017) [Netherlands], 1 March 2017, art. 14(2), <www.refworld.org>, dostęp 16 IV 2019.

32 Human Rights Council, Human rights and arbitrary deprivation of nationality: Report of the Secretary General, 19 December 2013, UN Doc. A/HRC/25/28, pkt 20-21. 
posiadanego obywatelstwa. Nie oznacza to natomiast, że w każdym przypadku zostanie to uznane za zgodne z prawem międzynarodowym. Odpowiednio do poszczególnych norm tego prawa decyzja o odebraniu obywatelstwa m.in. nie może nosić znamion arbitralności ${ }^{33}$. Wypada jednak $\mathrm{w}$ tym kontekście nadmienić, że samo pozbawienie jednostki obywatelstwa w związku z prowadzeniem przez nią działalności terrorystycznej nie pozwala jeszcze na konstatację, że każda taka decyzja będzie miała arbitralny charakter.

Wprawdzie sam zakaz arbitralnego pozbawienia obywatelstwa ma solidne umocowanie w prawie międzynarodowym, to jednak ustalenie dokładnej treści tego zakazu może nastręczać pewnych problemów. W raporcie wyjaśniającym do Europejskiej konwencji o obywatelstwie zaznaczono, że zakaz arbitralnego pozbawiania obywatelstwa powinien być rozważany zarówno w aspekcie materialnoprawnym, jak i proceduralnym. W pierwszym przypadku, aby pozbawienie obywatelstwa nie zostało ocenione jako arbitralne, musi być przewidziane w prawodawstwie krajowym, spełniać wymóg proporcjonalności zastosowanego środka, nie może mieć dyskryminacyjnego charakteru, prowadzić do powstania bezpaństwowości lub być stosowane ze względów politycznych. W wymiarze proceduralnym chodzi zaś o zapewnienie, że każda decyzja o pozbawieniu jednostki obywatelstwa będzie zawierała pisemne uzasadnienie i podlegała kontroli sądowej lub administracyjnej ${ }^{34}$. Zdaniem Rady Praw Człowieka pozbawienie obywatelstwa nie zostanie uznane za arbitralne, jeżeli służy ono realizacji uzasadnionego celu, stanowi relatywnie najmniej inwazyjny środek pozwalający na osiągnięcie tego celu oraz jest proporcjonalne do interesu, który państwo zamierza ochronić3 ${ }^{35}$.

Zbliżone rozumienie arbitralności zaprezentowali uczestnicy eksperckiego spotkania w Tunisie zwołanego w 2013 r. przez Biuro Wysokiego Komisarza ONZ ds. Uchodźców. W konkluzjach ze spotkania podkreślono, że bez względu na to, czy pozbawienie jednostki obywatelstwa skutkuje, czy też nie skutkuje powstaniem bezpaństwowości, to - aby nie zostało uznane za arbitralne - musi spełniać następujące warunki: powoływana przesłanka utraty obywatelstwa musi być przewidziana w prawodawstwie krajowym, przesłanka ta nie może być wykorzystywana w sposób dyskryminujący określone grupy, pozbawienie obywatelstwa musi odpowiadać wymogom konieczności oraz proporcjonalności, wreszcie muszą być przestrzegane niezbędne gwarancje proceduralne zabezpieczające przed możliwością nadużywania prawa przez władze ${ }^{36}$. Na tym tle stosunkowo ostrożne stanowisko prezentuje Trybunał Sprawiedliwości UE, który zdaje się

33 Confer art. 15 ust. 2 Powszechnej Deklaracji Praw Człowieka, Nowy Jork, 10 grudnia 1948 r., <www.refworld.org>, dostęp 16 IV 2019; art. 20 ust. 3 Amerykańskiej konwencji praw człowieka, op. cit.; art. 24 ust. 2 Konwencji Wspólnoty Niepodległych Państw o prawach człowieka i podstawowych wolnościach, Mińsk, 26 maja 1995 r., <www.refworld.org>, dostęp 16 IV 2019; art. 4 pkt c. Europejskiej konwencji o obywatelstwie, op. cit.; art. 18 ust. 1 lit. a Konwencji o prawach osób niepełnosprawnych, Nowy Jork, 13 grudnia 2006 r., <www.refworld.org>, dostęp 16 IV 2019.

34 Explanatory Report to the European Convention on Nationality..., § 36-37.

35 Human Rights Council, Human rights and arbitrary..., pkt 4.

36 United Nations High Commissioner for Refugees, Interpreting the 1961 Convention and avoiding statelessness resulting from loss and deprivation of nationality. Summary conclusions from the Expert Meeting held in Tunis, Tunisia, from 31 October to 1 November 2013, pkt 15-27; <www.refworld.org>, dostęp 16 IV 2019. 
utożsamiać arbitralność z działaniem władz bez wymaganej podstawy prawnej. Trybunał w głośnej sprawie Rottmann przeciwko Freistaat Bayern, oceniając możliwość odebrania jednostce obywatelstwa uzyskanego w wyniku oszustwa, stwierdził, że ,w przypadku, gdy państwo pozbawia daną osobę obywatelstwa z uwagi na dopuszczenie się przez nią podstępu, który został jej udowodniony, wówczas takiego pozbawienia obywatelstwa nie można uznać za decyzję arbitralną" ${ }^{\prime 37}$.

Mimo odnotowanych różnic w podejściu do wyznaczników arbitralności działania władz w sprawach związanych z pozbawieniem obywatelstwa za działalność terrorystyczną, w przyjętym standardzie oceny powinno przede wszystkim brać się pod uwagę dwa kluczowe elementy, których ryzyko pominięcia jest w tym przypadku największe. Po pierwsze, decyzja o pozbawieniu obywatelstwa musi mieć wyraźne podstawy w prawie krajowym. Oznacza to, że jeżeli przesłankę utraty obywatelstwa stanowi prowadzenie działalności terrorystycznej, wymagany jest uprzedni wyrok skazujący za przestępstwo tego typu popełnione w kraju lub za granicą. Samo podejrzenie popełnienia takiego przestępstwa nie jest jeszcze wystarczającą podstawą do pozbawienia obywatelstwa i może zostać uznane za działanie o charakterze arbitralnym ${ }^{38}$. Po drugie, istotne jest, aby stosowna decyzja została podjęta z poszanowaniem niezbędnych gwarancji proceduralnych, jakie przysługują obywatelowi w związku z sądowym lub administracyjnym rozpoznawaniem indywidualnej sprawy (ang. due process of law) ${ }^{39}$. Przestrzeganie wymienionych gwarancji zapewnia niezbędny stopień ochrony przed arbitralnością władz oraz umożliwia kwestionowanie decyzji o pozbawieniu obywatelstwa, uważaną jest przez zainteresowanego za bezpodstawną, nieodpowiadającą zasadom konieczności i proporcjonalności albo też mającą dyskryminacyjny charakter ${ }^{40}$.

Sugerowane ujęcie arbitralności znajduje podstawę w orzecznictwie Europejskiego Trybunału Praw Człowieka [dalej: ETPC]. Wprawdzie Konwencja o ochronie praw człowieka i podstawowych wolności z $1950 \mathrm{r}$. [dalej: EKPC], ani żaden z jej protokołów dodatkowych, nie zapewniają odrębnej ochrony obywatelstwa, niemniej w kilku orzeczeniach ETPC postanowił odnieść się do elementów charakteryzujących arbitralne pozbawienie obywatelstwa. Uznał bowiem, że gdy zachodzi taki przypadek, państwo może narazić się na zarzut naruszenia art. 8 EKPC, gwarantującego prawo do poszanowania życia prywatnego i rodzinnego ${ }^{41}$. W sprawie Ramadan przeciwko Malcie Trybunał stwierdził, że maltańskie władze, pozbawiając skarżącego obywatelstwa, nie działały w sposób arbitralny. W tym celu odnotował, że kwestionowana decyzja została podjęta zgodnie z obowiązującym prawem, a skarżący miał pełną możliwość przedsta-

${ }^{37}$ Janko Rottmann przeciwko Freistaat Bayern, wyrok Trybunału Sprawiedliwości UE (wielka izba) z 2 marca 2010 r., sprawa C-135/08, ECLI:EU:C:2010:104, pkt 53.

${ }^{38}$ Tak np. vide United Nations High Commissioner for Refugees, Interpreting the 1961 Convention..., pkt 27.

${ }^{39}$ Vide Human Rights Council, Resolution 13/2 on human rights and arbitrary deprivation of nationality, 14 April 2010, UN Doc. A/HRC/RES/13/2, pkt 10.

${ }^{40} \mathrm{~T}$. Molnár, The prohibition of arbitrary deprivation of nationality under international law and EU law: New perspectives, „Hungarian Yearbook of International Law and European Law” 2014, s. 77-78.

${ }^{41}$ Genovese przeciwko Malcie, wyrok ETPC z 11 października 2011 r., skarga nr 53124/09, pkt 30. 
wienia swoich racji oraz argumentów przed właściwym komitetem, a następnie także przed sądem ${ }^{42}$.

Do analogicznych wniosków Trybunał doszedł, badając dopuszczalność skargi K2 przeciwko Zjednoczonemu Królestwu. Sprawa jest o tyle interesująca, że dotyczyła bezpośrednio osoby zaangażowanej w działalność terrorystyczną w państwie trzecim. Dokonując oceny, czy pozbawienie skarżącego brytyjskiego obywatelstwa nie nosiło znamion arbitralności, również i w tym przypadku ETPC odwołał się do testu zastosowanego w sprawie Ramadan. W pierwszej kolejności podjął próbę ustalenia, czy działania brytyjskich władz miały podstawę w odpowiednich przepisach prawa krajowego. Stwierdziwszy to, Trybunał sprawdził, czy w trakcie postępowania zmierzającego do pozbawienia obywatelstwa przestrzegano przysługujących skarżącemu gwarancji proceduralnych. Zauważył, że choć skarżący, który przebywał wówczas w Sudanie, nie brał czynnego udziału w rozpatrywaniu jego indywidualnej sprawy, cały czas był reprezentowany przez swojego pełnomocnika, miał zatem możliwość oddziaływania na kierunki prowadzonego postępowania, przedkładania stosownych wniosków czy podważania zgromadzonych przeciwko niemu dowodów. Trybunał nie zgodził się z argumentem skarżącego, że brak jego osobistego udziału w toczącym się postępowaniu o odebranie obywatelstwa automatycznie czyni wydaną decyzję arbitralną. Zaznaczył bowiem, że art. 8 EKPC nie można interpretować w ten sposób, że nakłada on na strony obowiązek każdorazowego ułatwienia wjazdu na swoje terytorium osobie uprzednio pozbawionej obywatelstwa tylko w celu umożliwienia jej bezpośredniego udziału w toczącym się postępowaniu ${ }^{43}$. W praktyce oznacza to, że taka osoba przy próbie wjazdu na terytorium państwa swojego poprzedniego obywatelstwa będzie uznana za obywatela państwa trzeciego, zakładając, że posiada inne obywatelstwo, lub za apatrydę, jeżeli takiego obywatelstwa nie posiada.

\section{POZBAWIENIE OBYWATELSTWA ZA DZIALALNOŚĆ TERRORYSTYCZNĄ A BEZPAŃSTWOWOŚĆ}

W prawie międzynarodowym bezpaństwowość definiowana jest jako nieposiadanie obywatelstwa żadnego państwa. Nie ma przy tym znaczenia, czy jednostka ma możliwość nabycia obywatelstwa innego państwa w bliższej lub dalszej przyszłości. Istotne jest natomiast to, że w momencie podejmowania przez właściwy organ decyzji

${ }^{42}$ Ramadan przeciwko Malcie, wyrok ETPC z 21 czerwca 2016 r., skarga nr 76136/12, pkt 86-89.

${ }^{43} \mathrm{~K} 2$ przeciwko Zjednoczonemu Królestwu, decyzja ETPC z 9 marca 2017 r. w sprawie dopuszczalności skargi, skarga nr 42387/13, niepubl. Szerzej na temat okoliczności faktycznych sprawy oraz decyzji Trybunału vide ECHR, Depriving a suspected terrorist of his citizenship was lawful under the Convention, Press Release, ECHR 084 (2017), <hudoc.echr.coe.int>, dostęp 17 IV 2019. Warto jednocześnie zauważyć, że z notki prasowej Trybunału nie wynika, aby skarżący został uprzednio skazany w Zjednoczonym Królestwie za działalność terrorystyczną. Brytyjskie władze wskazywały jedynie na istnienie przekonujących dowodów mających świadczyć o związkach skarżącego z somalijską organizacją terrorystyczną Al-Shabaab. W przypadku braku odpowiedniego wyroku skazującego, nawet gdy prawo krajowe pozwala na pozbawienie obywatelstwa tylko na podstawie zarzutów o działalność terrorystyczną, podjęta w tym zakresie decyzja może jednak budzić pewne obawy o możliwą arbitralność w postępowaniu władz. 
o pozbawieniu obywatelstwa zainteresowana osoba nie posiada innego obywatelstwa, stając się apatrydą ${ }^{44}$. Takie rozumienie bezpaństwowości znalazło potwierdzenie w art. 1 Konwencji o statusie bezpaństwowców z 1954 r., w który stwierdzono, że bezpaństwowcem jest „osoba, która nie jest uważana za obywatela w świetle prawa któregokolwiek państwa"45. Komisja Prawa Międzynarodowego uznała, że definicja zawarta w tej konwencji stanowi element prawa zwyczajowego ${ }^{46}$.

Należy zauważyć, że pozbawienie obywatelstwa, które prowadzi do wystąpienia bezpaństwowości, nie może być traktowane jako arbitralne per se, a w konsekwencji jako niezgodne $\mathrm{z}$ prawem międzynarodowym ${ }^{47}$. Wystarczy nadmienić, że zgodnie $\mathrm{z}$ konwencją z 1961 r. w określonych sytuacjach możliwe jest odebranie jednostce obywatelstwa, nawet jeśli w wyniku tego stanie się ona bezpaństwowcem. Możliwość taka wystąpi, np. jeśli osoba, która nabyła obywatelstwo w procesie naturalizacji, zamieszkuje stale w innym państwie przez okres co najmniej siedmiu kolejnych lat i nie złożyła przed właściwym organem oświadczenia o zamiarze utrzymania posiadanego obywatelstwa ${ }^{48}$. To samo dotyczy przypadku, gdy nabycie obywatelstwa nastąpiło w wyniku posłużenia się podstępem lub oszustwem ${ }^{49}$. Strony konwencji mają ponadto możliwość skorzystania z klauzuli stand still i złożenia deklaracji o zachowaniu — istniejących w momencie podpisywania, ratyfikacji lub przystępowania do konwencji — określonych przesłanek utraty obywatelstwa dopuszczonych prawem krajowym. Przesłanki te sprowadzają się do podjęcia przez jednostkę pewnych działań świadczących o naruszeniu obowiązku wierności i lojalności wobec państwa obywatelstwa. Jedną z takich przesłanek wskazanych wprost w konwencji jest, wspominane wcześniej, postępowanie przynoszące poważną szkodę żywotnym interesom państwa ${ }^{50}$. Również Europejska konwencja

${ }^{4}$ United Nations High Commissioner for Refugees, The concept of stateless persons under international law. Summary conclusions from the Expert Meeting held in Prato, Italy, from 27 to 28 May 2010, pkt I.B.16, <www.refworld.org>, dostęp 17 IV 2019.

${ }^{45}$ Convention relating to the status of stateless persons, New York, 28 September 1954; UNTS, t. 360 , s. 117.

46 International Law Commission, Draft Articles on diplomatic protection with commentaries (2006), „Yearbook of the International Law Commission” 2006, t. II, part II, draft article 8 with commentary, s. 36.

${ }^{47}$ Tak np. vide Parliamentary Assembly of the Council of Europe, Withdrawing nationality as a measure to combat terrorism: A human rights-compatible approach?. Report by Ms Tineke Strik, adopted on 7 January 2019 by the Committee on Legal Affairs and Human Rights, Doc. 14790, Explanatory memorandum, pkt 14, <www.assembly.coe.int>, dostęp 17 IV 2019.

${ }^{48}$ Confer art. 8 ust. 2 (a) w zw. z art. 7 ust. 4 Konwencji o ograniczeniu bezpaństwowości.

49 Confer ibidem, art. 8 ust. 2 (b).

${ }^{50}$ Confer ibidem, art. 8 ust. 3. Stosowne deklaracje złożyły dotąd: Austria, Brazylia, Gruzja, Irlandia, Jamajka, Litwa, Nowa Zelandia, Hiszpania, Tunezja oraz Zjednoczone Królestwo. Lista wszystkich złożonych deklaracji oraz zastrzeżeń do konwencji o ograniczeniu bezpaństwowości dostępna jest pod adresem: <https://treaties.un.org>, dostęp 17 IV 2019. Z treści poszczególnych oświadczeń należy wnosić, że państwa zarezerwowały dla siebie znaczny margines swobody oceny tego, jakie działania jednostki będą mieścić się w ramach wyłączeń wskazanych w art. 8 ust. 3 konwencji. Szerzej na ten temat vide L. Bücken, R. de Groot, Deprivation of nationality under article 8 (3) of the 1961 Convention on the reduction of statelessness, „Maastricht Journal of European and Comparative Law” 2018, t. 25, nr 1, s. 45-50. 
o obywatelstwie z 1997 r. daje podstawę do pozbawienia jednostki obywatelstwa, które w efekcie prowadzi do uzyskania statusu bezpaństwowca. W tym przypadku przesłanką jest nabycie obywatelstwa za pomocą oszustwa, podania fałszywych informacji lub ukrycia przez wnioskodawcę jakiegokolwiek istotnego faktu ${ }^{51}$.

Zdecydowanie mniej jednoznaczna jest natomiast odpowiedź na pytanie, czy państwa, które nie są stronami Europejskiej konwencji o obywatelstwie albo też nie złożyły formalnej deklaracji na podstawie art. 8 ust. 3 Konwencji o ograniczeniu bezpaństwowości lub nie są jej stronami, mają możliwość pozbawienia jednostki obywatelstwa za działalność terrorystyczną w sytuacji prowadzącej do powstania bezpaństwowości. W związku z tym, że ustalenie praktyki wszystkich członków społeczności międzynarodowej w tym zakresie byłoby niezwykle trudne, tytułem przykładu warto jedynie wskazać rozwiązania obowiązujące w dwóch wybranych państwach, mianowicie w Australii i we Francji. Australijska ustawa o obywatelstwie z 2007 r. zezwala na odebranie obywatelstwa osobie powyżej 14. roku życia, która pełni za granicą służbę lub świadczy usługi na rzecz organizacji uznawanej za terrorystyczną. Warunkiem jest jednak, aby osoba taka posiadała jednocześnie obywatelstwo innego państwa ${ }^{52}$. Z kolei we francuskim kodeksie cywilnym w art. 25 przewidziano, że po zatwierdzeniu decyzji przez Radę Stanu zainteresowany może być pozbawiony swojego obywatelstwa w przypadku skazania za przestępstwo o charakterze terrorystycznym ,z wyjątkiem przypadku, gdy stawałby się w ten sposób bezpaństwowcem"s3. Obowiązywanie tego przepisu potwierdziła później w jednym ze swoich rozstrzygnięć Rada Konstytucyjna, oddalając zarzut jego możliwej niekonstytucyjności ${ }^{54}$.

Rozwiązania przyjęte w Australii oraz we Francji oczywiście nie pozwalają jeszcze na formułowanie kategorycznych wniosków w przedmiocie zwyczajowego charakteru normy zakazującej pozbawiania obywatelstwa za działalność terrorystyczną, jeśli miałoby to prowadzić do bezpaństwowości. Faktem jest natomiast, że wymienione państwa nie są związane żadnymi zobowiązaniami traktatowymi, które obligowałyby je do ograniczenia przypadków bezpaństwowości, a mimo to umożliwiły, zgodnie ze swoim ustawodawstwem, pozbawienie obywatelstwa z zastrzeżeniem, że nie będzie to skutkować wystąpieniem bezpaństwowości. Jest to godne odnotowania, ponieważ oba te podmioty doświadczyły już w przeszłości skutków działań terrorystycznych i mają pełną świadomość, że ich obywatele służą w strukturach różnych organizacji prowadzących taką działalnośćs ${ }^{55}$. Wymowne jest ponadto, że zarówno Francja, jak i Australia należą do grupy

${ }^{51}$ Confer art. 7 ust. 3 Europejskiej konwencji o obywatelstwie.

${ }_{52}$ Australian Citizenship Act 2007, No. 20, including amendments up to Act No. 67, 2018, Part II, Division 3, Section 33AA, 35, 35A, <www.legislation.gov.au>, dostęp 17 IV 2019.

${ }_{53}$ French Civil Code, op. cit., art. 25.

${ }^{54}$ Mr Ahmed S. [Revocation of citizenship], The Constitutional Council Decision no. 2014-439 QPC of 23 January 2015, pkt 11 oraz 19; <www.conseil-constitutionnel.fr>, dostęp 17 IV 2019.

55 Vide np. A. Chrisafis, France prepares for return of jihadists after US withdraws, „The Guardian” z 31 stycznia 2019 r., <www.theguardian.com>, dostęp 17 IV 2019; J. Power, G'Day Jihad: The threat posed by Australians in Syria and Iraq, <www.internationalaffairs.org.au>, dostęp 17 IV 2019. 
państw, które w ostatnich latach zdecydowanie zaostrzyły przepisy w kwestii dopuszczalności pozbawienia obywatelstwa za czyny o charakterze terrorystycznym.

Przypuszczenie, iż państwa faktycznie mogą do pewnego stopnia kierować się przekonaniem, że pozbawienie obywatelstwa za działalność terrorystyczną nie jest uzasadnione, jeśli prowadzi do powstania bezpaństwowości, potwierdza praktyka Zjednoczonego Królestwa. Rząd brytyjski złożył odpowiednią deklarację na podstawie art. 8 ust. 3 Konwencji o ograniczeniu bezpaństwowości, w której zastrzegł możliwość pozbawienia obywatelstwa w sytuacji „,postępowania przynoszącego poważną szkodę żywotnym interesom Jej Królewskiej Wysokości”. Złożenie deklaracji powinno więc oznaczać, że zachowania wyczerpujące znamiona wskazanej w niej przesłanki będą dawać podstawy do odebrania jednostce obywatelstwa, niezależnie od tego, czy stanie się ona apatrydą, czy nie. Tymczasem aktualnie obowiązujące w Zjednoczonym Królestwie przepisy prawne stanowią, że klauzula ,żywotnych interesów” może być wykorzystywana przez ministra spraw wewnętrznych, ale m.in. pod warunkiem, że ma on uzasadnione podstawy, aby przypuszczać, że osoba mająca zostać pozbawiona brytyjskiego obywatelstwa jest w stanie nabyć obywatelstwo innego państwa ${ }^{56}$. Chociaż przyznanie ministrowi spraw wewnętrznych tak szerokich, a przede wszystkim ocennych uprawnień może budzić pewne wątpliwości, nie zmienia to faktu, że nie jest on władny pozbawić danej osoby obywatelstwa, jeżeli osoba ta stawałaby się bezpaństwowcem. Stanowisko to potwierdził brytyjski Sąd Najwyższy w 2013 r. w sprawie Al-Jedda. Stwierdził wówczas, że odebranie brytyjskiego obywatelstwa skarżącemu, podejrzewanemu o wspieranie irackich terrorystów, było niezgodne z odpowiednimi przepisami krajowymi, ponieważ czyniło zainteresowanego apatrydą ${ }^{57}$.

\section{WNIOSKI KOŃCOWE}

Przeprowadzona analiza pozwala stwierdzić, że normy prawa międzynarodowego zasadniczo nie stoją na przeszkodzie dopuszczalności pozbawienia obywatelstwa za działalność terrorystyczną. Ważne jest natomiast, aby państwa wykorzystujące taką możliwość posiadały świadomość istnienia pewnych ograniczeń i warunków, które decydują o legalności stosowanych zgodnie z ich prawem rozwiązań. Najczęstszym problem, który pojawia się w tym kontekście, jest narażanie się państw na zarzut arbitralnego pozbawienia obywatelstwa lub doprowadzenia do powstania przypadków bezpaństwowości. Ryzyko arbitralnego postępowania władz staje się większe, gdy decyzje o pozbawieniu obywatelstwa podejmowane są $\mathrm{w}$ czasie nieobecności zainteresowanego w państwie macierzystym.

Poważniejszych wątpliwości nie budzi na ogół pozbawienie obywatelstwa za działalność terrorystyczną osób posiadających podwójne obywatelstwo. Tak też było w większości spraw, które uczyniono przedmiotem analizy i które doczekały się sądowych rozstrzygnięć. Problematyczne okazuje się natomiast odebranie obywatelstwa,

${ }^{56}$ British Nationality Act 1981, art. 40 (4A); <www.legislation.gov.uk>, dostęp 17 IV 2019.

57 Secretary of State for the Home Department (Appellant) v Al-Jedda (Respondent), The Supreme Court, Judgment of 9 October 2013, [2013] UKSC 62. 
które skutkuje powstaniem bezpaństwowości. Jakkolwiek zgodnie z konwencją z 1961 r. zezwala się na takie rozwiązanie pod warunkiem złożenia odpowiedniej deklaracji, to jednak wydaje się, że w praktyce państwa idą w nieco innym kierunku. Trzeba mieć ponadto na uwadze jedną ważną rzecz. Zakładając, że w stosunku do osoby, którą pozbawiono obywatelstwa, zostaną zainicjowane formalne kroki zmierzające do wydalenia jej z państwa pobytu, pojawi się pytanie, do jakiego państwa już jako apatryda miałaby zostać wydalona. Nie ulega wątpliwości, że w tego typu sytuacjach przyjęcie na swoje terytorium osoby, której udowodniono działalność terrorystyczną, zależy wyłącznie od dobrej woli państwa trzeciego.

\section{BIBLIOGRAFIA}

ŹRÓDŁA

Act on the Acquisition of Danish Nationality (amended to 2004) [Denmark], 7 June 2004, <www. refworld.org>.

Amerykańska konwencja praw człowieka, San Jose, 22 listopada 1969 r., <www.refworld.org>. Arabska Karta Praw Człowieka, Kair, 15 września 1994 r., <www.refworld.org>.

Australian Citizenship Act 2007, No. 20, including amendments up to Act No. 67, 2018, <www. legislation.gov.au>.

British Nationality Act 1981, <www.legislation.gov.uk>.

Convention on the reduction of statelessness, New York, 30 August 1961, „United Nations. Treaty Series", vol. 989.

Convention relating to the status of stateless persons, New York, 28 September 1954, „United Nations. Treaty Series", vol. 360.

Council of Europe, Nationality issues and the denial of residence in the context of the fight against terrorism - feasibility study (prepared by Mr. Andrew Walmsley), Strasbourg, 5 December 2006, Doc. CDCJ-BU (2006) 22.

European Parliament, Acquisition and loss of citizenship in EU Member States: Key trends and issues, <www.europarl.europa.eu>.

Europejska konwencja o obywatelstwie, Strasburg, 6 listopada 1997 r., „European Treaty Series” nr 166.

Explanatory Report to the European Convention on Nationality, Strasbourg, 6.11.1997, „European Treaty Series" nr 166.

Federal Law Concerning the Austrian Nationality (Nationality Act 1985) (last amended 2006) [Austria], 30 July 1985, <www.refworld.org>.

French Civil Code, <www.legifrance.gouv.fr>.

Human Rights Council, Human rights and arbitrary deprivation of nationality: Report of the Secretary General, 19 December 2013, UN Doc. A/HRC/25/28.

Human Rights Council, Resolution 13/2 on human rights and arbitrary deprivation of nationality, 14 April 2010, UN Doc. A/HRC/RES/13/2.

International Law Commission, Draft Articles on diplomatic protection with commentaries (2006), ,Yearbook of the International Law Commission” 2006, vol. II, part II.

International Law Commission, Third Report on the expulsion of aliens (By Mr. Maurice Kamto, Special Rapporteur), 19 April 2007, UN Doc. A/CN.4/581.

Konwencja o prawach osób niepełnosprawnych, Nowy Jork, 13 grudnia 2006 r., <www. refworld.org>. 
Konwencja Wspólnoty Niepodległych Państw o prawach człowieka i podstawowych wolnościach, Mińsk, 26 maja 1995 r., <www.refworld.org>.

Konwencja w sprawie niektórych zagadnień dotyczących konfliktu ustaw o obywatelstwie, Haga, 12 kwietnia 1930 r., „League of Nations Treaty Series”, t. 179, nr 4137.

Law for the Bulgarian Citizenship (last amended February 2013) [Bulgaria], 5 November 1998, $<$ www.refworld.org $>$.

Law No. 01-288/2 of 2008 on Montenegrin Citizenship (2014) [Montenegro], 21 February 2008, <www.refworld.org>.

Law No. 21/1991 on Romanian Citizenship [Romania], 5 April 1991, <www.refworld.org>.

Law of Mongolia on Citizenship (as amended on 7 December 2000) [Mongolia], 5 June 1995, $<$ www.refworld.org $>$.

Law on Citizenship of Bosnia and Herzegovina [Bosnia and Herzegovina], 27 July 1999, $<$ www.refworld.org $>$.

Letter dated 28 December 2018 from the Chair of the Security Council Committee established pursuant to resolution 1373 (2001) concerning counter-terrorism addressed to the President of the Security Council, Annex: Addendum to the guiding principles on foreign terrorist fighters (2018), UN Doc. S/2018/1177.

Netherlands Nationality Act, 2010 (as amended in 2017) [Netherlands], 1 March 2017, <www. refworld.org>.

OSCE Office for Democratic Institutions and Human Rights, Guidelines for addressing the threats and challenges of ,foreign terrorist fighters" within a human rights framework (2018), $<$ www.osce.org>.

Parliamentary Assembly of the Council of Europe, Withdrawing nationality as a measure to combat terrorism: A human rights-compatible approach?. Report by Ms Tineke Strik, adopted on 7 January 2019 by the Committee on Legal Affairs and Human Rights, Doc. 14790, Explanatory memorandum, <assembly.coe.int >

Powszechna Deklaracja Praw Człowieka, Nowy Jork, 10 grudnia 1948 r., <www.refworld.org>.

Protokół nr 4 do Konwencji o ochronie praw człowieka i podstawowych wolności, gwarantujący niektóre prawa i wolności, inne niż zawarte w Konwencji i w pierwszym Protokole dodatkowym do Konwencji, Strasburg, 16 września 1963 r., „European Treaty Series” nr 046.

United Nations High Commissioner for Refugees, Interpreting the 1961 Convention and avoiding statelessness resulting from loss and deprivation of nationality. Summary conclusions from the Expert Meeting held in Tunis, Tunisia, from 31 October to 1 November 2013; $<$ www.refworld.org $>$.

United Nations High Commissioner for Refugees, The concept of stateless persons under international law. Summary conclusions from the Expert Meeting held in Prato, Italy, from 27 to 28 May 2010, <www.refworld.org>.

United Nations Security Council Resolution 2178, UN Doc. S/RES/2178 (2014), 24 September 2014.

United Nations Office on Drugs and Crime, Foreign terrorist fighters. Manual for judicial training institutes South-Eastern Europe, Vienna 2017.

Orzeczenia i decyzje

Genovese przeciwko Malcie, wyrok Europejskiego Trybunału Praw Człowieka z 11 października 2011 r., skarga nr 53124/09.

Janko Rottmann przeciwko Freistaat Bayern, wyrok Trybunału Sprawiedliwości UE (wielka izba) z 2 marca 2010 r., sprawa C-135/08, ECLI:EU:C:2010:104. 
K2 przeciwko Zjednoczonemu Królestwu, decyzja Europejskiego Trybunału Praw Człowieka z 9 marca 2017 r. w sprawie dopuszczalności skargi, skarga nr 42387/13.

Mr Ahmed S. [Revocation of citizenship], The Constitutional Council Decision no. 2014-439 QPC of 23 January 2015, <www.conseil-constitutionnel.fr>.

National decrees issued in Tunis and Morocco, Permanent Court of International Justice (PCIJ), Advisory Opinion No. 4 of 7 February 1923, PCIJ Publ. Ser. B, No. 4, 1923.

Nottebohm case (Liechtenstein $v$. Guatemala), International Court of Justice, Judgment of 6 April 1955, ICJ Reports 1955.

Ramadan przeciwko Malcie, wyrok Europejskiego Trybunału Praw Człowieka z 21 czerwca 2016 r., skarga nr 76136/12.

Secretary of State for the Home Department (Appellant) v. Al-Jedda (Respondent), The Supreme Court, Judgment of 9 October 2013, [2013] UKSC 62.

PIŚMIENNICTWO

Bierzanek R., Symonides J., Prawo międzynarodowe publiczne, Wolters Kluwer, Warszawa 2005.

Bücken L., de Groot R., Deprivation of nationality under article 8 (3) of the 1961 Convention on the reduction of statelessness, „Maastricht Journal of European and Comparative Law” 2018, t. 25, nr 1, https://doi.org/10.1177/1023263x17754036.

Czapliński W., Międzynarodowe aspekty obywatelstwa, ,Ruch Prawniczy, Ekonomiczny i Socjologiczny" 1984, z. 3.

Czapliński W., Problematyka obywatelstwa w aktualnych pracach Rady Europy, „Studia Europejskie" 1998, nr 2.

Dynia E, Obywatelstwo w świetle prawa międzynarodowego, „Annales Universitatis Mariae Curie-Skłodowska. Sectio G” 2000, t. XLVII.

Esbrook L., Citizenship unmoored: Expatriation as a counter-terrorism tool, „University of Pennsylvania Journal of International Law" 2016, t. 37, nr 4.

Harasimiuk D.E., Obywatelstwo UE - element tożsamości narodowej, europejskiej, czy jedynie dodatkowy status obywateli państw członkowskich?, „Ius Novum” 2017, nr 3.

Mantu S., Contingent citizenship. The law and practice of citizenship deprivation in international, european and national perspectives, Brill Nijhoff, Leiden-Boston 2015.

Molnár T., The prohibition of arbitrary deprivation of nationality under international law and EU law: New perspectives, „Hungarian Yearbook of International Law and European Law” 2014.

Prawo międzynarodowe publiczne. Wybór orzecznictwa, red. P. Daranowski, J. Połatyńska, C.H. Beck, Warszawa 2011.

Ronen Y., Transition from illegal regimes under international law, Cambridge University Press, Cambridge 2011, https://doi.org/10.1017/CBO9780511978142.

See S., Returning foreign terrorist fighters: A catalyst for recidivism among disengaged terrorists, „Counter Terrorist Trends and Analyses” 2018, t. 10, nr 6.

Walters W., Deportation, expulsion, and the international police of aliens, „Citizenship Studies” 2002, t. 6, nr 3, https://doi.org/10.1080/1362102022000011612.

Wasiuta O., Wasiuta S., Rekrutacja bojowników-cudzoziemców do ISIS, „Annales Universitatis Paedagogicae Cracoviensis-Studia de Securitate et Educatione Civili” 2017, nr 7.

MATERIAEY PRASOWE

Chrisafis A., France prepares for return of jihadists after US withdraws, „,The Guardian”, 31 I $2019,<$ www.theguardian.com>.

Department of Home Affairs of Australia, Neil Prakash stripped of Australian citizenship, $<$ minister.homeaffairs.gov.au $>$. 
European Court of Human Rights, Depriving a suspected terrorist of his citizenship was lawful under the Convention, Press Release, ECHR 084 (2017), <hudoc.echr.coe.int>.

Ochab E.U., Attempts to address the issue of foreign terrorist fighters continue, „Forbes”, 22 II 2019, <www.forbes.com>.

Power J., G'Day Jihad: The threat posed by Australians in Syria and Iraq, <www.internatio nalaffairs.org.au>.

Vedaschi A., Graziani Ch., Citizenship revocation in Italy as a counter terrorism measure, $<$ www.verfassungsblog.de $>$. 